\title{
Descriptive and prescriptive taxonomies
}

\section{Jim Endersby}

In 1992, Lord Dainton rose to address Britain's House of Lords, to introduce the results of an investigation into the state of systematic biology - which he defined as the description, naming and classification of organisms. His findings were alarming. Major scientific institutions where such research was done were being starved of funds and there were fewer jobs for classifiers. Yet British universities were nevertheless unable to train sufficient people to fill even these. The great national collections were neither properly maintained nor used. Similar problems were common in most countries. $^{1}$

Dainton was a distinguished scientist who knew precisely why systematics mattered, but in addressing the Lords he acknowledged that for some of his listeners "the words "systematic biology" had little significance'. So he explained that the science was vital to conservation and was in the process of being revolutionised by 'DNA studies, molecular biological tools, computers and information technology'. Yet despite this innovation, Dainton acknowledged, systematics was losing out in competition with 'the more glamourous branches of biology such as molecular biology', because 'it is rather patronisingly perceived as "comparatively unoriginal". Dainton's speech summarised the twin problems of low status and limited funding that beset systematic biology throughout the twentieth century; at the same time, he inadvertently provided a vivid insight into why those problems had persisted. In an effort to get his audience's attention, he reminded them of 'those few school and college contemporaries who liked nothing better than to collect and mount wild flowers or insects (especially it seemed to me beetles, butterflies and moths) and then proceed to name them according to a binomial system indicating their genus and species.. ${ }^{2}$ No doubt, many a noble lord nodded in happy recollection of some eccentric contemporary, but what Dainton described hardly sounded like cutting-edge science.

The problems highlighted by Dainton and his committee were not new ones, and they are a reminder that classification is pre-eminently a set of practices: collecting, preserving, storing and organising. ${ }^{3}$ In the mid 1950s, the US Biology Council published a report on the state of American museum collections that identified issues similar to those identified by Dainton. ${ }^{4}$ In the same decade, Britain's Royal Society set up a committee to consider 'the need for taxonomists and provision of taxonomic training'. 5 They reported that training and funding were inadequate, and noted, as Dainton would 30 years later, that Britain was losing what had once been a global pre-eminence in the field. The report complained that taxonomy struggled to compete with newer branches of biology and needed more money. ${ }^{6}$

Twentieth-century taxonomy was largely shaped by such complaints about low status and inadequate funding, and the perception of classification as an old-fashioned, intellectually undemanding practice. If physics is traditionally the most prestigious of sciences, classification heads the list of those dismissed as mere 'stamp collecting'.7 Its practitioners often responded to these challenges by seeking to import advanced techniques from other branches of biology, but these innovations sometimes exacerbated the very problem they were intended to resolve. ${ }^{8}$ Dainton's argument in the 1990 s that systematics was changing rapidly because of recent advances in related sciences was very similar to those made by the Royal Society, 30 years earlier, about a 'revolution within taxonomy itself built on a novel and 'wide range of experimental data' together with a 'thorough rethinking of its philosophy'. 9 However, these reports were talking about two different revolutions (numerical taxonomy, or 
phenetics, in the 1960s, and phylogenetic systematics, or cladistics, in the 1990s). ${ }^{10}$ Both phenetics and cladistics were revolutionary new approaches, intended to free classification from its longstanding association with dusty museums in which idiosyncratic cataloguers fought to impose order on nature. Yet paradoxically, these (and other) revolutions often prompted bitter disputes that exacerbated the perception that systematic biology was too subjective and unstable to be taken seriously.

Unambiguously named species were, as many systematists asserted, the fundamental building blocks upon which biology was built, yet the supposed experts seemed unable to agree on the basic methods for describing them.

The problems of low funding and status were thus linked to a long- running dispute about the fundamental purpose of systematics. Some considered it a simple matter of providing a stable set of names for other scientists to use; neither glamorous nor exciting work, but if a classification did not produce a stable nomenclature, it surely served no purpose. By contrast, others within the systematics community were equally confident that this lack of intellectual ambition doomed systematics to low status: unless they set themselves more ambitious - and more explicitly scientific - goals, taxonomists deserved to be underfunded and undervalued. The central paradox that emerged from this contrast between stability and science was that every effort to make taxonomy more stable made it appear even less scientific, while every effort to make it more scientific seemed to make it less stable.

\section{Describing or prescribing}

Taxonomy's 'science vs stability' contest began (like many aspects of modern biology), with Charles Darwin, who knew the world of systematics well (having devoted eight years to detailed taxonomic work on barnacles). Since at least the late eighteenth century, much day-to- day classification had been done using convenient but 'artificial' systems. Meanwhile naturalists sought a truly 'natural system' of classification, one that described the order within nature itself. However, the source of the natural order was much disputed; for some it represented God's plan for the Creation, while others sought strictly naturalistic descriptions, based on less-than-clear concepts such as the 'affinity' that apparently linked groups of organisms. In the Origin, Darwin announced a solution to this longstanding debate: 'the natural system is founded on descent with modification', therefore 'all true classification is genealogical'. Common descent was 'the hidden bond which naturalists have been unconsciously seeking, and not some unknown plan of creation'. Darwin claimed at one and the same time to have finally freed systematics from its shaky metaphysical foundations, and to have liberated his fellow classifiers from the banal business of 'putting together and separating objects more or less alike'. ${ }^{11}$ Classification would finally have clear, positive goals. In short, it would become a real science.

However, Darwin's potentially revolutionary announcement was accompanied by a deeply conservative one. Despite promising 'a considerable revolution in natural history', he assured systematists that they would 'be able to pursue their labours as at present'.12 Darwin's conservative revolution appealed to many systematists, not least because it did not necessitate renaming every specimen in their museums or herbaria. Instead, they could carry on as before, confident that they now had a more impressive, philosophical, rationale for their work. ${ }^{13}$

The elegant compromise embodied in Darwin's view was, however, unstable. The claim that 'all true classification is genealogical' was profoundly ambiguous. For some, it was merely descriptive; classification would gradually converge on a stable consensus because the 'hidden bond' of evolutionary descent underlay those similarities. A descriptive reading of Darwin meant there was really no need to change taxonomic practice; the natural (evolutionary) order would emerge in time. However, others saw Darwin's phrase as prescriptive, and took it to mean that classification was a tool with which to investigate phylogeny, i.e., the historical relationships between species. In effect, 
classification could now become a powerful tool with which to understand evolution, a mission that not only allowed but required taxonomists to abandon their traditional tasks of merely describing and naming.

Darwin's divided legacy was apparent in 1927, when a distinguished taxonomist, Francis Arthur Bather, argued that when it came to classification, practicality was paramount, a goal that was 'served best by a classification based on superficial and obvious characters, selected and arranged in an arbitrary manner'. ${ }^{14}$ Such an artificial classification might have practical uses, but Bather contrasted it with a classification that grouped those things 'that possess in common the greatest number of attributes', which he represented as more philosophically profound. 'Such a classification', he asserted, 'may be called SCIENTIFIC.'

Bather admitted that stable nomenclature must be classification's main purpose, while also acknowledging that only a scientific classification, 'by enabling us to predict', provided 'a means of advancing science'. Yet such advances seemed to come at the expense of stability, which led him to ask, 'Can any classification serve both purposes equally well?' He took his listeners on an erudite tour of the history of taxonomy, from Aristotle onward, elucidating the philosophical twists and pragmatic turns along the way. He credited the eighteenth-century French naturalist Michel Adanson with being the first to try and cut taxonomy's Gordian knot by sheer force, by classifying unknown plants using each of their characters in turn. This produced a set of different classifications, and Adanson assumed that those groups that reappeared in several of the classifications were genuinely natural ones. However, Adanson's method was not widely adopted; most nineteenth-century taxonomists tried to discover principles for deciding which of an organism's characteristics were the most important, and to base their classifications on these. This idea, which became known as the subordination of characters, argued that - for example - the colour of a flower was much less important to the plant than the anatomy of its reproductive system, hence the latter provided a more useful guide to classification. This concept could, Bather noted, be readily adapted to an evolutionary interpretation, and taxonomists had been trying to form one ever since Darwin. Yet while 'many paid lip-service to evolution', no actual method for detecting evolutionary patterns had been proposed, much less implemented. Somewhat despairingly, he concluded that 'important though phylogeny is as a subject of study, it is not necessarily the most suitable basis for classification'.

Nevertheless, Bather suggested that in the twentieth century 'the last word is with the experimental geneticist', on the assumption that 'the ultimate element... of biological classification is the gene'. He therefore proposed that 'some modern analytical palaeontologist... should join forces with a mathematical geneticist, and see how far the two sets of facts can be harmonized'. These comments reflect the excitement that gripped early-twentieth-century biology, when many hoped that the modern laboratory sciences would come to the rescue of taxonomy. Various factors, such as the rediscovery of Mendel's work, Hugo de Vries's mutation theory, and early breakthroughs in biochemistry, had produced new funding for what would become known as the Science of Life. ${ }^{15}$ These innovative forms of biology made taxonomy look increasingly outdated. ${ }^{16}$ However, while some were moving nature into the lab, others were trying to take the lab out into nature. Ecologists sought to bring some of the mathematical and experimental rigour of the laboratory sciences to analysing wild populations. ${ }^{17}$ Many taxonomists saw such work as close to their own concerns, and tried to apply their traditional field- and herbarium-based approaches to taxonomic questions in tandem with the methods of modern ecology. ${ }^{18}$ Practitioners of what would soon become known as experimental taxonomy traced the origins of their approach to Frederic E. Clements's Research Methods in Ecology (1905). ${ }^{19}$ Clements, a US Professor of Plant Physiology, promised them that 'the general use of experiment will leave much less opportunity for the personal equation than is at present the case'. ${ }^{20}$ The key problem for botanists was that plants grew in different ways in different environments (so stunted alpines collected on a mountain might be the same species as those collected at sea level). 
Without direct access to the plant's genes, how were genuine species to be distinguished from what were becoming known as 'ecotypes', non-heritable adaptations to local habitats?

Transplantation experiments promised a solution to this dilemma. Clements's enthusiasm for them was shared by Harvey Monroe Hall, unofficial curator of the herbarium at the University of California. Hall and Clements obtained funding from the Carnegie Institution for a series of experiments using transplantation methods devised by the Swedish naturalist Gote Wilhelm Turesson, which involved growing plants from diverse habitats in a uniform environment, to identify genuine inherited variations. ${ }^{21}$ Clements and Hall pioneered reciprocal transplantation: swapping two plants between stations, placing each into the hole left by the other, to ensure 'an exact reversal of habitats'. Their research developed into a more formal, long-term programme in the late 1920s, led by Hall, who brought the Danish geneticist and ecologist Jens Clausen to California, as part of a Carnegie-funded interdisciplinary group at Stanford that included taxonomist David Keck and physiologist William Hiesey. ${ }^{22}$

Clausen, Keck and Hiesey used three field stations - Stanford (30 ft/ $9 \mathrm{~m}$ above sea level), Mather $(4,600 \mathrm{ft} / 1,400 \mathrm{~m})$ and Timberline $(10,000 \mathrm{ft} / 3,000 \mathrm{~m})$ - to transplant various plants, particularly of yarrow \{Achillea) species (Figure 27.1). The team used a combination of notes, photographs, numbered stakes and maps to keep track of their plants and relied on 'careful yearly weeding' to prevent 'contamination' from surrounding plants. Despite the relatively straightforward methods involved, these early experiments proved too difficult to sustain; many specimens were lost either to shock from transplantation or from the depredations of "campers and grazing animals'. Alternatives were tried, such as moving whole plants and their soil ("sod transplants'), but these proved too difficult to transport over mountain roads and it remained hard to identify plants. Finally, they turned to cloning plants in the lab, to create a genetically identical stock, which could then be grown in a variety of habitats. ${ }^{23}$

For a period of about 30 years, experimental taxonomy was widely practised. But transplantation experiments were complex, time-consuming and expensive; even with the combined resources of the Carnegie Institution and Stanford University, Clausen and his colleagues had to reduce the number of experimental sites by 1940. Moreover, they had to admit that their work rested on "close familiarity with the plants themselves in the different environments'. As a result, 'experiments like these can never replace laboratory tests under complete control'. ${ }^{24}$ Despite the attempt to replace idiosyncrasy with experimental rigour, individual expertise and the tacit knowledge needed to conduct successful fieldwork remained essential; taxonomy still appeared more like connoisseurship than science.

Although experimental taxonomy would eventually lead to important work on such topics as plant evolution, it did not seem to resolve taxonomic difficulties. 25 Taxonomists had long been divided into 'lumpers' (who define taxonomic groups broadly in an effort to reduce their number) and 'splitters' (who multiply groups and names in the pursuit of greater precision); experimental taxonomy largely failed to resolve such disputes, since there were still no objective criteria for defining species (let alone higher taxonomic groups). ${ }^{26}$ Among the practical objections was that new methods involved a new terminology which, opponents claimed, created more confusion than clarity, for example in Turesson's coinage of terms like 'genecological', 'coenospecies', 'ecospecies' and 'ecotype'. ${ }^{27}$ Finally, experimental work was slow by comparison with the analysis of herbarium specimens. As one taxonomist noted, such studies were in the case of trees, perhaps a work of centuries. One can hardly expect taxonomists and phytogeographers to wait so long!'28

Experimental taxonomy, which took place in both labs and at field stations, was seized on as an example of the rapprochement between different biological traditions. ${ }^{29}$ It caught the attention of Julian Huxley, who coined the name 'modern evolutionary synthesis' for this joint endeavour. 
Although not a systematist himself, he agreed to edit the collection The New Systematics, noting its rather 'presumptuous' title: 'For the new systematics is not yet in being: before it is born, the mass of new facts and ideas which the last two or three decades have hurled at us must be digested, correlated, and synthesized.'30

Huxley's introduction to this revolution in progress conveyed the excitement gripping systematics which, 'even a quarter of a century ago' appeared wholly 'empirical and lacking in unifying principles'. By contrast, it was now 'one of the focal points of biology', which detected 'evolution at work' and hence 'the world is our laboratory, evolution itself our guinea pig'. ${ }^{11}$ Population genetics provided tools for understanding the power of natural selection, and made it possible to reject the claim that all taxonomic units were merely artificial. ${ }^{2}$ However, despite the rhetoric (embodied in the term 'new' in the book's title, but 'systematics' was also intended to sound more dynamic), the old problem of how to read the relationship between evolution and classification remained.33 Among the volume's authors some took the prescriptive view - that phylogenetics was the only valid approach. 34 Others, by contrast, argued that all classification was primarily practical, shaped by the purpose for which it had been devised, so there could be no single, correct or best classification. 35

As Keith Vernon has argued, the major problem with the new approaches was that they made no tangible difference to the field's prospects or funding. Indeed, some saw the emphasis on evolution as undermining the significance of traditional, museum-based classificatory work. Huxley's definition of systematics as 'detecting evolution at work' reduced its scope 'to the narrowest possible dimensions' and ignored 'the grand tasks of collecting, describing, naming, comparing and grouping the results of one thousand million years of evolution'. ${ }^{6}$

\section{Phenetics and cladistics}

Even among those who accepted phylogeny as the basis for classification, substantial disagreements over methods persisted. 37 One approach to reducing the role of individual judgement was to devise mathematical methods for quantifying and measuring resemblance. The goal of mathematical taxonomy (which soon became known as phenetics) was to replace individual expert judgement with robust, objective methods. By aggregating the results of numerous different classificatory schemes, and eschewing a priori (and potentially circular) judgements about how to subordinate characters, the sheer weight of data would iron out any idiosyncrasies in specific taxonomists' work, creating a consensus classification that could be gradually improved with the addition of further data. ${ }^{8}$

Among the founders of this new approach was the British microbiologist Peter Henry Andrews Sneath, a doctor who hoped to improve the then-chaotic state of bacterial classification. Inspired by the numerical approach, but 'being averse to hack work', Sneath tried punch cards and sorting machines, then by chance made contact with a pioneering British computer company looking for new applications for their machines. Sneath was soon using computers for classificatory work.39 Meanwhile, in the US, an Austrian-born biologist, Robert Reuven Sokal, had done a PhD on classification and also studied statistical methods in biology. He became frustrated by what he saw as a lack of rigour in existing methods, leading to a now- celebrated bet with a fellow student, over a sixpack of beer - that he could do a better job classifying organisms by statistical means than by the traditional approach. $4^{\circ}$ Within a few weeks, Sokal had a purely algorithmic method of classification. He and Sneath, learning of each other's work, collaborated on a book, Principles of Numerical Taxonomy (1963) that explained the new approach. ${ }^{41}$

Some pursued the goal of objectivity with almost fanatical intensity. Paul Ehrlich promoted Sokal's method vigorously, predicting in 1961 that electronic data-processing equipment would soon be the 
systematises most important tool. When one taxonomist asked indignantly: 'You mean to tell me that taxonomists can be replaced by computers?', Ehrlich is said to have responded, 'No, some of you can be replaced by an abacus.' 42 Paradoxically, this attempt to raise the status of taxonomy by making it more objective threatened to lower the status of taxonomists themselves; like many white-collar workers, they faced the prospect of being replaced or deskilled by computers. For some, this was a fresh threat to the future of systematics; mathematical methods might provide the stability systematics had long sought, but at the expense of individual expertise, thus arguably making classification look more like office work than science.

Ernst Mayr, a leading figure among those who saw taxonomy as a key tool for investigating evolution, spoke for many critics when he wrote a long, negative review of Principles of Numerical Taxonomy. 43 His ire focused on what he saw as Sokal and Sneath's extremism. Given that they 'criticize just about every axiom and method of classical taxonomy', one would presume that 'all previously proposed classifications ought to be complete chaos': yet numerical methods had 'almost invariably... confirmed the orthodox classifications'.44 Mayr also objected to the pheneticists' refusal to weight the characters they were using, which seemed to go against the logic of taxonomy. Classification could not be a single, logical procedure that could be applied to any arbitrary set of objects; according to Mayr, 'a classification of organisms that deliberately ignores their historical information content is prone to be misleading or at best inefficient and uneconomical'.45 Mayr reasserted the prescriptive reading of Darwin's claim that 'all true classification is genealogical'. That reading underlay another taxonomic revolution that emerged in parallel (and sometimes in reaction) to phenetics: phylogenetic systematics, or cladistics. 46

The conventional history of cladistics traces its origins to Willi Hennig, an East German entomologist who took the claim that classifications ought to represent phylogeny more seriously than perhaps any previous taxonomist. However, Hennig realised that there was no simple method for converting the complexity of phylogenetic development into traditional classifications, exemplified by the Linnaean hierarchy. He instead attempted to identify groups which shared a common ancestor by analysing the distribution of characters. Characters of ancient origin (shared primitive characters, or symplesiomorphies in cladistic terminology) were too widely distributed to serve in identifying evolutionary relationships. Cladists therefore focused on more recently evolved characters (shared derived characters, or synapomorphies) in order to identify sister groups which shared a common ancestor more recently than with any other group. Such analyses produced hypothetical diagrams of relationships, known as cladograms (Figure 27.2).47 Although Hennig's first works appeared in the early 1950s, his German was heavy going, even for native speakers, hence his ideas made little impact before they appeared in English in $1966.4^{8}$ Yet, despite Hennig's importance as a founding father of cladistics, very similar methods were developed independently by systematists in Italy, Britain, Australia and New Zealand, the USA and Argentina. 49 Taxonomic communities worldwide shared similar long-standing concerns with the nature and status of their discipline (and, of course, many practical problems), and cladistics was a common response, which aimed to make taxonomy a tool for investigating evolution.

Historians love describing a good fight, and controversies within classification have been somewhat exaggerated as a result. (And the taxonomic community seems to boast more than its fair share of combative and uncompromising characters.) Nevertheless, it is possible to discern a preference for stable taxonomic categories among the pheneticists, whereas many of the cladists seemed to place a higher value on scientific innovation..$^{\circ}$ Although twentieth-century taxonomists largely agreed that evolution underpins classification, pheneticists tended to exclude evolutionary theorising from their work, confident that evolutionary patterns would necessarily emerge, while cladists took a prescriptive line, building theory into their work from the outset. Yet despite these differences, there was considerable common ground between phenetics and cladistics. For example, taxonomic 
methodologies began to converge as computers became cheap and ubiquitous. By the end of the twentieth century, virtually all taxonomists were using purely algorithmic methods. The result was that, despite the apparent triumph of cladistics in the twenty-first century, its daily practice owes a great deal to phenetics, not least in being highly automated. One key output generated by cladistic software is known as a 'consensus cladogram', in that it is the best hypothesis based on the available data - but perhaps it represents consensus at a more profound level?51

\section{Conclusion}

For systematists, the twentieth century ended more or less as it had begun: in 2002, the British government's Select Committee on Science and Technology complained that systematics was still inadequately funded. $5^{2}$ Apparently, little had changed since the Dainton Report.

As this chapter has shown, one common feature of the history of twentieth-century taxonomy was attempts to raise its status.53 Improving taxonomic ideas and methods, on which this chapter focuses, was crucial but issues such as institutional affiliations and links to other sciences - especially medicine - were also important. 54

Different groups argued that taxonomy could raise its status by tackling causal questions, becoming less idiosyncratic, or utilising less ambiguous data, such as molecular or chemical characters in place of traditional morphological ones. Even in this brief overview, it is clear that several schools of classification embodied more than one of these impulses. Although considerable work remains to be done, the abiding tension between stability and science seems clear. Stable classifications might not be glamorous, but they make classification essential, whereas innovative methods make potentially more exciting but also more fragile claims. This dispute remains unresolved, but a degree of consensus has emerged because of a common practical goal - to improve the status and funding of systematics. Given this goal, fractious public disputes about underlying philosophical and methodological principles perhaps appeared counterproductive. As Bather argued: 'All of us, like Aristotle, classify objects in various ways according to the end in view.'55 While those with different ends in view can never reach agreement, once ends are agreed, controversies over means tend to fade.

\section{Notes}

1. Hansard HL Deb (series 5), vol. DXXXVIII, CC1295-342 (9 July 1992) (Dainton, Frederick Sydney, 1992). All the quotes from Dainton here are from the Hansard record of this debate.

\section{Hansard HL Deb.}

3. J. Endersby, Imperial Nature: Joseph Hooker and the Practices of Victorian Science (Chicago, 2008), pp. 137-69.

4. K. Vernon, 'Desperately seeking status: evolutionary systematics and the taxonomists' search for respectability 1940-60', British Journal for the History of Science, 26:2 (1993), pp. 207-27, pp. 221-2.

5. E. J. H. Corner et al., Taxonomy: Report of a Committee Appointed by the Council of the Royal Society (London, 1963), p. 1.

6. Corner et al., Taxonomy, p. 10.

7. K. Johnson, 'Natural history as stamp collecting: a brief history', Archives of Natural History, 34:2 
(2007), pp. 244-58.

8. My thinking has been much influenced by the work of Keith Vernon, particularly 'Desperately seeking status' (fn. 4).

9. Corner et al., Taxonomy, p. 8.

10. Both the terms 'numerical phenetics' and 'cladistics' were coined by Ernst Mayr, and the proponents of these rival schemes did not initially adopt them: E. Mayr, 'Numerical phenetics and taxonomic theory', Systematic Zoology, 14:2 (1965), pp. 73-97, p. 78; D. L. Hull, Science as a Process: An Evolutionary Account of the Social and Conceptual Development of Science (Chicago, 1988), pp. 132-3. However, they are now so widespread that alternative terms would be unnecessarily confusing.

11. C. Darwin, On the Origin of Species by Means of Natural Selection: Or the Preservation of Favoured Races in the Struggle for Life (London, 1859), p. 421.

12. Darwin, Origin of Species, p. 484.

13. P. F. Stevens, 'Metaphors and typology in the development of botanical systematics 1690-1960, or the art of putting new wine in old bottles', Taxon, 33:2 (1984), pp. 169-211, p. 169; J. Endersby, 'Classifying sciences: systematics and status in mid-Victorian natural history', in M. Daunton (ed.), The Organisation of Knowledge in Victorian Britain (Oxford, 2005), pp. 61-86; J. Endersby, 'Lumpers and splitters: Darwin, Hooker and the search for order', Science 326:5959 (2009), pp. 14969.

14. F. A. Bather, 'Biological classification: past and future', Quarterly Journal of the Geological Society of London, 83 (1927), pp. lxii-civ. All quotes from Bather are from this source.

15. See J. Endersby, A Guinea Pig's History of Biology: The Plants and Animals Who Taught Us the Facts of Life (London, 2007); J. Endersby, 'Mutant utopias: evening primroses and imagined futures in early twentieth-century America', Isis, 104:3 (2013), PP- 471-5O3-

16. Vernon, 'Desperately seeking status', pp. 207-8.

17. F. N. Egerton, 'History of ecological sciences, part 48: formalizing plant ecology, about 1870 to mid-ig2os', The Bulletin of the Ecological Society of America, 94:4 (2013), pp. 341-78.

18. Much of the historiography of twentieth-century biology has been built around a narrative shaped by the supposed contest between naturalists and experimentalists, but the history of taxonomy illustrates why this is an oversimplification. See J. B. Hagen, 'Experimentalists and naturalists in twentieth-century botany: experimental taxonomy, 1920-1950', Journal of the History of Biology, 17:2 (1984), pp. 249-70, p. 250.

19. Hagen, 'Experimentalists and naturalists', p. 251.

20. F. E. Clements, Research Methods in Ecology (Lincoln, NE, 1905), P-13-

21. J. Clausen, D. D. Keck and W. M. Hiesey, Experimental Studies on the Nature of Species, 6 vols. (Washington, DC, 1940), vol. I, p. 4;

A. Müntzing, 'Gote Wilhelm Turesson', Taxon. 20:5/6 (1971), PP- 773-5; Hagen, 'Experimentalists and naturalists', pp. 251-4. 
22. V. B. Smocovitis, 'Botany and the evolutionary synthesis, 1920-1950', in M. Ruse (ed.), The Cambridge Encyclopedia of Darwin and Evolutionary Thought (Cambridge, 2013), pp. 313-21, p. 317.

23. Clausen et al., Experimental Studies, pp. 15-18.

24. Clausen et al., Experimental Studies, pp. 6-7, p. 25.

25. V. B. Smocovitis, 'G. Ledyard Stebbins, Jr. and the evolutionary synthesis (1924-1950)', American Journal of Botany 84:12 (1997), pp. 1625-37; 'Darwin's botany in the Origin of Species', in M. Ruse and R. J. Richards (eds.), The Cambridge Companion to the 'Origin of Species' (Cambridge, 2009), pp. 216-36; V. B. Smocovitis, 'The "Plant Drosophila": E. B. Babcock, the genus Crepis, and the evolution of a genetics research program at Berkeley, 1915-1947', Historical Studies in the Natural Sciences, 39:3 (2009), pp. 300-55.

26. J. W. Gregor, V. McM. Davey and J. M. S. Lang, 'Experimental taxonomy I: experimental garden technique in relation to the recognition of the small taxonomic units', The New Phytologist, 35-4 (1936), pp. 323-6; P. A. Rydberg, 'Scylla or Charybdis?', in B. M. Duggar (ed.), Proceedings of the International Congress of Plant Sciences, Ithaca, New York, August 16-23,O26 (Menasha, WI, 1929), pp. 1539-51-

27. Vernon, 'Desperately seeking status', pp. 210-11.

28. K. Fasgri, 'Some fundamental problems of taxonomy and phylogenetics', Botanical Review, 3:8 (1937), pp. 400-23, p. 401.

29. E. Mayr and W. Provine (eds.), The Evolutionary Synthesis: Perspectives on the Unification of Biology, 2nd edn (Cambridge, MA, 1998); V. B. Smocovitis, Unifying Biology: The Evolutionary Synthesis and Evolutionary Biology (Princeton, 1996).

30. J. S. Huxley, 'Foreword', in J. S. Huxley (ed.), The New Systematics (Oxford, 1940), n.p.

31. 'Introductory: towards the new systematics', in Huxley (ed.), The New Systematics, pp. 1-46, pp. 1-2.

32. Huxley 'Introductory', p. 3.

33. M. P. Winsor, 'The English debate on taxonomy and phylogeny, 1937-1940', in History and Philosophy of the Life Sciences, 17 (1995), pp. 227-52; Vernon, 'Desperately seeking status', p. 212.

34. For example, W. T. Caiman, 'The meaning of biological classification', Nature, 136: 3427 (1935), pp. 9-10, p. 10.

35. J. S. Lennox Gilmour and S. M. Walters, 'Two early papers on classification', Plant Systematics and Evolution, 167 (1936, 1937 [reprinted 1989]), pp. 97-107, p. 100.

36. R. E. Blackwelder and A. A. Boyden, 'The nature of systematics', Systematic Zoology (1952), pp. 26-33, P- $3^{\circ}$, quoted in Vernon, 'Desperately seeking status', p. 223.

37. Stevens, 'Metaphors and typology', pp. 169-70.

38. Hull, Science as a Process, pp. 120-5; K. Vernon, 'The founding of numerical taxonomy', British Journal for the History of Science, 21:2 (1988), pp. 143-59, P-148; M. P. Winsor, 'Setting up 
milestones: Sneath on Adanson and Mayr on Darwin', in D. M. Williams and P. L. Forey (eds.), Milestones in Systematics (Boca Raton, 2004), PP-1-17-

39. P. H. A. Sneath, 'Some thoughts on bacterial classification', Journal of General Microbiology, 17 (1957), pp. 184-200; P. H. A. Sneath, 'The application of computers to taxonomy', Journal of General Microbiology, 17 (1957), pp. 201-26; P. H. A. Sneath, 'Early experience with computers', Binary: The Newsletter of the Society for General Microbiology Computer Club, 1 (1985), pp- 5-7-

40. Hull, Science as a Process, p. 119; Vernon, 'The founding of numerical taxonomy', p. 151.

41. K. Vernon, “A truly taxonomic revolution? Numerical taxonomy, 1957-1970', Studies in the History and Philosophy of the Biological and Biomedical Sciences, 32:2 (2001), pp. 315-41, pp. 315-16.

42. Hull, Science as a Process, p. 121.

43. See E. Mayr, E. G. Linsley and R. L. Usinger, Methods and Principles of Systematic Zoology (New York, 1953); also Hull, Science as a Process, p. 107; Vernon, 'Truly taxonomic revolution', pp. 208-9.

44. Mayr, 'Numerical phenetics and taxonomic theory', pp. 73-4.

45. Mayr, 'Numerical phenetics and taxonomic theory', p. 76, emphasis added.

46. See note 8 .

47. Hull, Science as a Process, p. 131; R. Craw, 'Margins of cladistics: identity, difference and place in the emergence of phylogenetic systematics, 1864-1975', in P. E. Griffiths (ed.), Trees of Life: Essays in Philosophy of Biology (Dordrecht, 1992), pp. 65-106, p. 67; P. L. Forey, Cladistics: A Practical Course in Systematics (Oxford, 1992); H. Gee, Deep Time: Cladistics, the Revolution in Evolution (London, 2001); B. Hennig and A. Kluge, 'Willi Hennig', available online at https://cladistics.org/willi-hennig/.

48. W. Hennig, Phylogenetic Systematics (Champaign, IL, 1966); Hull, Science as a Process, pp. 1446.

49. Craw, 'Margins of cladistics'.

50. I discuss some of the rhetorical aspects of recent taxonomy in J. Endersby, "The realm of hard evidence": novelty, persuasion and collaboration in botanical cladistics', Studies in History and Philosophy of Biological and Biomedical Sciences, 32:2 (2001), pp. 343-60.

51. Dean argued that controversy in classification was an ideal case to test the premises of the strong programme in the sociology of scientific knowledge, because there are no 'facts of the matter' that can resolve taxonomic disputes: J. P. Dean, 'Controversy over classification: a case study from the history of botany', in B. Barnes and S. Shapin (eds.), Natural Order: Historical Studies of Scientific Culture (Beverly Hills, 1979), pp. 1-30.

52. Select Committee appointed to consider Science and Technology, 'What on Earth? The threat to the science underpinning conservation', House of Lords Session 2002-3, 3rd Report (London, 2003).

53. Vernon, 'Desperately seeking status', p. 209.

54. A further key question not tackled here, for want of space, is the gendered nature of systematics. Systematics seems even more male dominated than comparable sciences at the same time, but the reasons for this require further research. 
55. Bather, 'Biological classification', p. lxiv. 